\title{
QUANTIFICATION OF SEDIMENTARY ORGANIC CARBON STORAGE AND TURNOVER OF TIDAL MANGROVE STANDS IN SOUTHERN CHINA BASED ON CARBON ISOTOPIC MEASUREMENTS
}

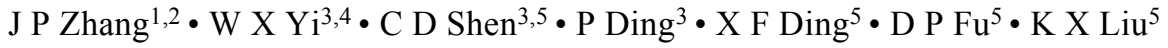

ABSTRACT. Mangrove ecosystems are highly productive and play an important role in tropical and global coastal carbon (C) budgets. However, sedimentary organic carbon (SOC) storage and turnover in mangrove forests are still poorly understood. Based on $\mathrm{C}$ isotopic measurements of sediment cores of 2 mangrove stands in southern China, SOC density was $431.77 \mathrm{Mg} \mathrm{ha}^{-1}$ at site 1 (a Aegiceras corniculatum-dominated high tidal stand) and $243.65 \mathrm{Mg} \mathrm{ha}^{-1}$ in site 2 (a Bruguiera gymnorrhiza + Kandelia candel-dominated middle tidal stand). SOC $\delta^{13} \mathrm{C}$ values at both mangrove sites ranged from $-29.4 \%$ to $-26.0 \%$. SOC $\delta^{13} \mathrm{C}$ was enriched with depth at $20-50 \mathrm{~cm}$ at site 1 , which possibly resulted from preferential microbial decomposition. SOC $\delta^{13} \mathrm{C}$ at site 2 experienced frequent tidal flushing, and presented relatively stable values with depth. A bomb- ${ }^{14} \mathrm{C}$-based SOC turnover model indicated that turnover times of SOC at $20-50 \mathrm{~cm}$ at site 1 were $4.44-26.04 \mathrm{yr}$. Modern $\mathrm{C}$ input from abundant roots might account for the very short SOC turnover times at these subsurface layers. As a result, our study suggested that tidal processes had a great influence on SOC storage and turnover in mangrove forests.

\section{INTRODUCTION}

Wetlands represent perhaps the largest sinks of carbon (C) in terrestrial soils (Chmura et al. 2003; Choi and Wang 2004). Located at the intertidal zone, mangrove wetlands have the characteristics of high productivity and low ratio of decomposition to net primary production (Jennerjahn and Ittekkot 2002; Gonneea et al. 2004). Mangrove ecosystems, therefore, are regarded as efficient $C$ sinks for atmospheric $\mathrm{CO}_{2}$ (Choi and Wang 2004; Gonneea et al. 2004; Bouillon et al. 2008; Tamooh et al. 2008). Although understanding sedimentary organic carbon (SOC) dynamics in mangrove ecosystems will help us to better constrain global oceanic-C budgets (Bouillon et al. 2003, 2008; Kristensen et al. 2008), mangrove ecosystems have been ignored in most global $\mathrm{C}$ budgets. Chmura et al. (2003) estimated that the top $50 \mathrm{~cm}$ of global mangrove forest soils contains as much as $5 \mathrm{Pg} \mathrm{C}$. SOC storage and dynamics in mangrove ecosystems therefore deserve our attention.

$\mathrm{C}$ isotopes are widely used to reconstruct ecological process and to trace ecological activity (Bouillon and Bottcher 2006; West et al. 2006), and the use of C isotopes has greatly improved our understanding of the $\mathrm{C}$ cycle in underground ecosystems (Staddon 2004). $\delta^{13} \mathrm{C}$ combined with other indicators has been used to determine the sources (mangrove-derived, oceanic, or terrestrial) of organic $\mathrm{C}$ in mangrove wetlands (Bouillon et al. 2003; Gonneea et al. 2004). $\delta^{13} \mathrm{C}$ is also useful in the study of SOC decomposition in different soil layers. However, there are few reports on the variations of SOC content and $\delta^{13} \mathrm{C}$ with depth in mangrove ecosystems (Zhang et al. 2012), although such studies are common in terrestrial soils (Balesdent et al. 1993; Boutton 1996; Ehleringer et al. 2000; Wynn et al. 2006). ${ }^{14} \mathrm{C}$ serves as a powerful tool to study the $\mathrm{C}$ cycle. Based on bomb ${ }^{14} \mathrm{C}$, produced by atmospheric thermonuclear weapons testing, many studies have modeled the turnover rates of $\mathrm{C}$ over decadal timescales in terrestrial ecosystems (Cherkinsky and Brovkin 1993; Townsend et al. 1995; Trumbore 1996; Chen et al. 2002; Telles et al. 2003). Using the bomb- ${ }^{14} \mathrm{C}$-based turnover

\footnotetext{
${ }^{1}$ Key Laboratory of Vegetation Restoration and Management of Degraded Ecosystems, South China Botanical Garden, Chinese Academy of Sciences, Guangzhou 510650, China.

${ }^{2}$ Graduate University of Chinese Academy of Sciences, Beijing 100039, China.

${ }^{3}$ Key Laboratory of Isotope Geochronology and Geochemistry, Guangzhou Institute of Geochemistry, Chinese Academy of Sciences, Guangzhou 510640, China.

${ }^{4}$ Corresponding author. Email: yiweixi@gig.ac.cn.

${ }^{5}$ State Key Laboratory of Nuclear physics and Technology, Peking University, Beijing 100871, China.
}

(C) 2013 by the Arizona Board of Regents on behalf of the University of Arizona

Proceedings of the 21st International Radiocarbon Conference edited by A J T Jull \& C Hatté

RADIOCARBON, Vol 55, Nr 2-3, 2013, p 1665-1674 
model (Harkness et al. 1986), Choi and Wang (2004) have found that turnover times of SOC in soil layers at $0-10 \mathrm{~cm}$ were $16-31,18-57$, and $10-38$ yr in low, middle, and high tidal flats, respectively. Modeling SOC turnover in coastal wetlands, and especially in mangrove forests, has been carried out in some previous studies (Woodroffe 1992; Matsui 1998; Tam and Wong 1998; Middleton and McKee 2001; Jennerjahn and Ittekkot 2002; Gonneea et al. 2004; Khan et al. 2007; Zhang et al. 2007).

In this study, we estimated SOC storage and modeled SOC turnover in mangrove forests in southern China based on analyses of C and its isotopes. The specific objectives were to determine (1) SOC storage of high and middle tidal mangrove stands, (2) the variations of $\mathrm{SOC} \delta^{13} \mathrm{C}$ with depth at the 2 sites, and (3) SOC turnover rates in mangrove forests.

\section{MATERIALS AND METHODS}

\section{Sites}

The 2 study sites were located on the west coast of the Leizhou Peninsula, about $70 \mathrm{~km}$ northwest of Zhanjiang City, and are part of the Zhanjiang Mangrove National Nature Reserve, the largest mangrove reserve in China. Sediment cores were excavated in rarely disturbed natural mangrove forests (Figure 1), which had an area of approximately 270 ha and are more than $80 \mathrm{yr}$ old. Site 1 was located at the high tidal flat and was dominated by a pioneer Aegiceras corniculatum community. Site 2 was located at the middle tidal flat and was dominated by a middle-to-late-stage Bruguiera gymnorrhiza and Kandelia candel community.

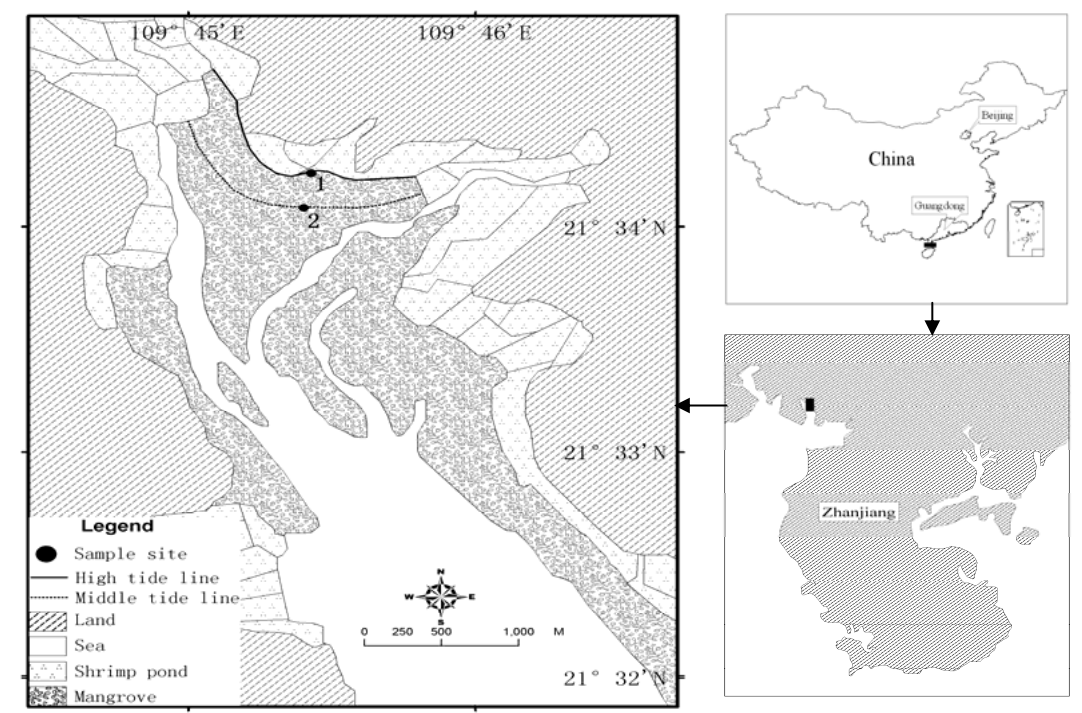

Figure 1 Locations of sediment cores at the 2 sites in mangrove forests, southern China: 1 : Aegiceras corniculatum site; 2: Bruguiera gymnorrhiza + Kandelia candel site.

In 2005 , we established three $10 \times 10 \mathrm{~m}$ quadrants around each site for the study of community structure. Plant height and diameter at breast height $(\mathrm{DBH})$ of each individual were recorded. Three 20 -cm sediment cores were taken from each of the $10 \times 10 \mathrm{~m}$ quadrats randomly to form a mixed sample. Salinity and $\mathrm{pH}$ were measured using an optical refractometer and a $\mathrm{pH}$ meter, respectively. Samples were oven-dried at $90^{\circ} \mathrm{C}$ for $24 \mathrm{hr}$ to remove water. Analysis of total $\mathrm{N}$ and total $\mathrm{P}$ followed 
Arnold (1986) and Robert et al. (1997). Usually, Eh of the waterlogged mangrove sediment was less than or equal to $100 \mathrm{mV}$ (McKee 1993). Table 1 summarizes the plant height and DBH, and properties of the top $20 \mathrm{~cm}$ of sediment at the 2 sites.

Table 1 Plant height, DBH, and properties of the top $20 \mathrm{~cm}$ sediment at 2 mangrove sites in southern China. Site 1 was located at the high tidal flat and was dominated by a pioneer Aegiceras corniculatum community. Site 2 was located at the middle tidal flat and was dominated by a middle-to-late-stage Bruguiera gymnorrhiza and Kandelia candel community.

\begin{tabular}{llllllll}
\hline & \multirow{2}{*}{$\begin{array}{l}\text { Dominant } \\
\text { Site }\end{array}$} & \multirow{2}{*}{$\begin{array}{l}\text { Average } \\
\text { species }\end{array}$} & Average & \multicolumn{4}{c}{ Sediment property } \\
\cline { 5 - 7 } & height $(\mathrm{cm})$ & $\mathrm{DBH}(\mathrm{cm})$ & Salinity $(\%)$ & $\mathrm{pH}$ & Total N $(\%)$ & Total P $(\%)$ \\
\hline 1 & A. corniculatum & 225 & 2.30 & 25.30 & 6.03 & 0.23 & 0.05 \\
2 & B. ymnorrhiza & 220 & 5.60 & 27.50 & 6.10 & 0.18 & 0.06 \\
& K. candel & 270 & 3.70 & & & & \\
\hline
\end{tabular}

For both sites, the mean annual temperature is $22.9^{\circ} \mathrm{C}$, and the average temperature in the coldest month (January) is $15.5^{\circ} \mathrm{C}$. The annual average precipitation is $1711 \mathrm{~mm}$, with the rainfall typically occurring from April to October. The average annual relative humidity is $80 \%$. The tidal regime is diurnal, and the average tidal amplitude is $2.52 \mathrm{~m}$, with a maximum of $6.25 \mathrm{~m}$ (He et al. 2007).

\section{Sediment Sampling}

During the ebb tide in June 2006, 1 sediment core (11 cm in diameter and $50 \mathrm{~cm}$ in length) was excavated from each site. Visible characteristics of the sediment are provided in Table 2. The cores were divided into segments based on depth and the characteristics of sediment and roots. The sampling interval was $2 \mathrm{~cm}$ for the surface $20 \mathrm{~cm}$ depth, and $5 \mathrm{~cm}$ for the $20-50 \mathrm{~cm}$ depth. These sediment segments were transported to the Carbon Isotope Laboratory of the Guangzhou Institute of Geochemistry, where they were frozen at $-26^{\circ} \mathrm{C}$ for later analyses.

Table 2 Visible characteristics of sediment cores at 2 mangrove sites, southern China. Site 1 was located at the high tidal flat and was dominated by a pioneer Aegiceras corniculatum community. Site 2 was located at the middle tidal flat and was dominated by a middle-to-late-stage Bruguiera gymnorrhiza and Kandelia candel community.

\begin{tabular}{lcl}
\hline Site & $\begin{array}{l}\text { Depth } \\
(\mathrm{cm})\end{array}$ & Characteristics \\
\hline 1 & $0-20$ & $\begin{array}{l}\text { Black sludge with high organic matter content, mixed with some red solid, granular structure, } \\
\text { very loose, abundant plant debris and roots, full of crustacean and molluscan macrofauna }\end{array}$ \\
& $20-50$ & Grayish black, half sludge, large roots (root amount decreasing with depth), less plant debris \\
2 & $0-25$ & Black, sludge, loose, abundant plant roots and macrofauna, occasionally brown solid \\
& $25-50$ & Grayish black, half sludge, large roots \\
\hline
\end{tabular}

\section{Carbon Isotope Analyses}

The frozen sediment segments were thawed to room temperature. After visible roots and fragmentary stones were removed, a 20- to 35-g subsample of each segment was freeze-dried under vacuum for $48 \mathrm{hr}$, ground using a mortar and pestle, and then passed through a 1-mm screen to remove rootlets and coarse sand. The subsamples were acid-treated using $2 \mathrm{M} \mathrm{HCl}$ to remove carbonate and then rinsed repeatedly with distilled water until a neutral $\mathrm{pH}$ was reached. Water was removed by ovendrying at $90{ }^{\circ} \mathrm{C}$ for $24 \mathrm{hr}$.

The subsamples for ${ }^{13} \mathrm{C}$ and ${ }^{14} \mathrm{C}$ analysis were then loaded into sealed, evacuated quartz tubes and combusted with $\mathrm{CuO}$ at $860^{\circ} \mathrm{C}$ for $2 \mathrm{hr}$. The $\mathrm{CO}_{2}$ generated was cryogenically purified with dry ice 


\section{$J$ P Zhang et al.}

and liquid nitrogen. SOC content was calculated from the quantity of $\mathrm{CO}_{2}$ generated from the subsamples. SOC density was calculated by multiplying SOC content by the bulk density and thickness of sediment layer. According to Ren et al. (2008), the average bulk density used for the calculation of SOC density could be $2.6 \times 10^{3} \mathrm{~kg} \mathrm{~m}^{-3}$.

Stable carbon isotope ratios in a portion of the generated $\mathrm{CO}_{2}$ were determined using a Finnigan MAT-251 mass spectrometer with a precision of $0.2 \%$ at the State Key Laboratory of Loess and Quaternary Geology, CAS. Results were expressed as $\delta^{13} \mathrm{C}$, in per mil deviations from the International Pee Dee belemnite $(\mathrm{PDB})$ standard: $\delta^{13} \mathrm{C}=\left[\left({ }^{13} \mathrm{C} /{ }^{12} \mathrm{C}\right)_{\text {sample }} /\left({ }^{13} \mathrm{C} /{ }^{12} \mathrm{C}\right)_{\text {standard }}-1\right] \times 1000$. The other portion of the generated $\mathrm{CO}_{2}$ was catalytically reduced to graphite accelerator mass spectrometry (AMS) targets using the method of Vogel et al. (1987). The ${ }^{14} \mathrm{C} /{ }^{12} \mathrm{C}$ ratios were determined in the generated graphite using AMS at the Institute of Heavy Ion Physics of Peking University. ${ }^{14} \mathrm{C}$ data were all corrected for isotopic fractionation of ${ }^{13} \mathrm{C}$ of $-25 \%$. Results were reported as $\Delta^{14} \mathrm{C}$, in parts per thousand of the ${ }^{14} \mathrm{C} /{ }^{12} \mathrm{C}$ ratio from that of an absolute standard (oxalic acid decay-corrected to 1950) (Stuiver and Polach 1977): $\Delta \Delta^{14} \mathrm{C}=\left[\left({ }^{14} \mathrm{C} /{ }^{12} \mathrm{C}\right)_{\text {sample }} /\left({ }^{14} \mathrm{C} /{ }^{12} \mathrm{C}\right)_{\text {standard }}-1\right] \times 1000$.

\section{Bomb- ${ }^{14} \mathrm{C}$-Based SOC Turnover Model}

For the samples with $\Delta^{14} \mathrm{C}$ greater than zero, bomb ${ }^{14} \mathrm{C}$ can be used to trace short-term SOC turnover at decade scales (Cherkinsky and Brovkin 1993; Chen et al. 2002). The equations used to calculate the turnover rates are

$$
\begin{gathered}
\frac{I(1955)}{I_{0}}=\frac{m}{m+\lambda} \\
I(t)=I(t-1)-(m+\lambda) \cdot I(t-1)+m \cdot I_{0}(t)
\end{gathered}
$$

where $I(1955)$ is the SOC ${ }^{14} \mathrm{C}$ activity in $1955, I(t)$ is the SOC ${ }^{14} \mathrm{C}$ activity in the year of sampling $(t>1955), I(t-1)$ is the $\mathrm{SOC}{ }^{14} \mathrm{C}$ radioactivity in year $(t-1), I_{0}(t)$ is the ${ }^{14} \mathrm{C}$ activity in the atmosphere in year $t, I_{0}$ is the ${ }^{14} \mathrm{C}$ activity of oxalic acid II, $\lambda$ is the ${ }^{14} \mathrm{C}$ decay constant $\left(1 / 8267 \mathrm{yr}^{-1}\right)$, and $m$ is the SOC turnover rate $\left(\mathrm{yr}^{-1}\right)$.

Equation 1 describes the SOC ${ }^{14} \mathrm{C}$ activity of a stable and closed section. Equation 2 is a mathematical expression for the dynamics of ${ }^{14} \mathrm{C}$ activity of SOC that is exchanging carbon with atmospheric $\mathrm{CO}_{2}$. The SOC ${ }^{14} \mathrm{C}$ activity in year $t$ is determined by that in year $(t-1)$, the ${ }^{14} \mathrm{C}$ loss attributable to natural decay of ${ }^{14} \mathrm{C}$ and $\mathrm{SOC}$ decomposition, and the incorporation of ${ }^{14} \mathrm{C}$ from atmosphere in year $t$ through formation of new organic matter.

Values of $I_{0}(t)$ in 1955-2006 were obtained from the previous studies (Hua and Barbetti 2004; Levin and Kromer 2004; Levin et al. 2008). During numerical simulation, 1 value of $m$ was selected first, and then $I(1955)$ was calculated by Equation 1 . The values for $I(1955)$ and $m$ were then put into Equation 2, and the SOC ${ }^{14} \mathrm{C}$ activity in the sampling year (2006) was obtained by iterative calculation.

\section{RESULTS}

\section{The A. corniculatum-Dominated High Tidal Stand (Site 1)}

SOC content at site 1 increased from $5.4 \%$ at $0-2 \mathrm{~cm}$ to $6.4 \%$ at $6-8 \mathrm{~cm}$, and then generally decreased with the increment of depth at $8-50 \mathrm{~cm}$. The lowest SOC content was $1.3 \%$ at $40-50 \mathrm{~cm}$ (Figure 2a). The calculated SOC density to a depth of $50 \mathrm{~cm}$ at site 1 was $431.77 \mathrm{Mg} \mathrm{ha}^{-1}$. SOC $\delta^{13} \mathrm{C}$ values were relatively constant in the upper $20-\mathrm{cm}$ layer, then became gradually less negative with 
increasing depth at $20-50 \mathrm{~cm}$. SOC $\delta^{13} \mathrm{C}$ values throughout the sediment core ranged from $-29.4 \%$ o to $-26.6 \%$ (Figure $2 b$ ).
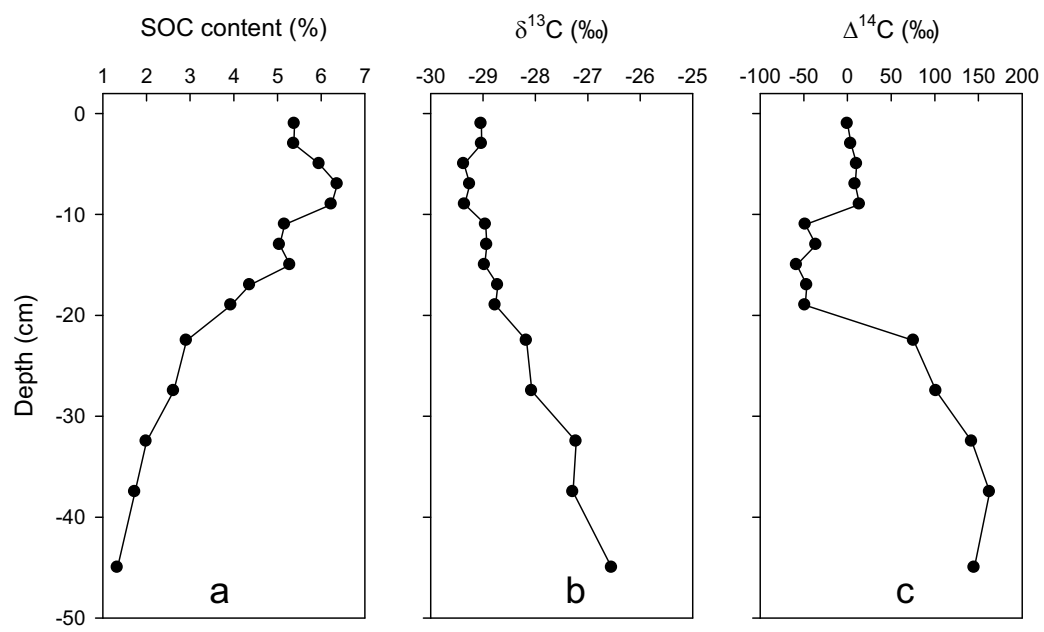

Figure 2 Vertical patterns in the sediment core from the Aegiceras corniculatum site (site 1): (a) SOC content; (b) SOC $\delta^{13} \mathrm{C}$; (c) $\mathrm{SOC} \Delta^{14} \mathrm{C}$.

The curve describing the vertical distribution of SOC $\Delta^{14} \mathrm{C}$ values could be divided into 3 sections. The first section covered the uppermost 10 -cm sediment layer, with $\Delta{ }^{14} \mathrm{C}$ values gradually increasing from $0.1 \%$ at $0-2 \mathrm{~cm}$ to $13.8 \%$ at $8-10 \mathrm{~cm}$. The second section was represented by the 10 $20 \mathrm{~cm}$ sediment layer, with $\Delta^{14} \mathrm{C}$ values varying between $-58.1 \%$ and $-36.0 \%$. The third section dominated the sediment at the $20-50 \mathrm{~cm}$ layer, presenting gradually increasing $\Delta^{14} \mathrm{C}$ values with depth with $75.8 \%$ at $20-25 \mathrm{~cm}$ and $145.2 \%$ at $40-50 \mathrm{~cm}$ (Figure $2 \mathrm{c}$ ). Reasonable values of SOC turnover rates for samples with $\Delta^{14} \mathrm{C}$ greater than zero were shown in Table 3. Turnover rates ranged from 0.04 to $0.23 \mathrm{yr}^{-1}$ at the $20-50 \mathrm{~cm}$ sediment layers.

Table 3 SOC turnover of the Aegiceras corniculatum-dominated high tidal stand (site 1), southern China.

\begin{tabular}{llc}
\hline Depth $(\mathrm{cm})$ & Turnover rate $\left(\mathrm{yr}^{-1}\right)$ & Turnover time $(\mathrm{yr})$ \\
\hline $20-25$ & 0.23 & 4.44 \\
$25-30$ & 0.12 & 8.32 \\
$30-35$ & 0.07 & 14.84 \\
$35-40$ & 0.04 & 26.04 \\
$40-50$ & 0.06 & 15.50 \\
\hline
\end{tabular}

\section{The B. gymnorrhiza + K. candel-Dominated Middle Tidal Stand (Site 2)}

SOC content at site 2 was stable more or less throughout $0-50 \mathrm{~cm}$, and covered $1.67-2.24 \%$ (Figure 3a). SOC density to a depth of $50 \mathrm{~cm}$ at site 2 was $243.65 \mathrm{Mg} \mathrm{ha}^{-1}$. At site 2 , SOC $\delta^{13} \mathrm{C}$ values remained almost stable at $0-50 \mathrm{~cm}$, although they fluctuated slightly in the top $20 \mathrm{~cm}$. The mean SOC $\delta^{13} \mathrm{C}$ value for $0-50 \mathrm{~cm}$ was $-26.4 \%$ (Figure $3 \mathrm{~b}$ ). SOC $\Delta^{14} \mathrm{C}$ values in all the sediment layers at site 2 were greater than zero, and gradually exhibited enrichment with depth from $19.5 \%$ at the surface $0-2 \mathrm{~cm}$ to $182.1 \%$ at the bottom $40-50 \mathrm{~cm}$, with the exception of $-17.5 \%$ at the $4-6 \mathrm{~cm}$ level and $-13.4 \%$ at $6-8 \mathrm{~cm}$, respectively (Figure $3 \mathrm{c}$ ). 

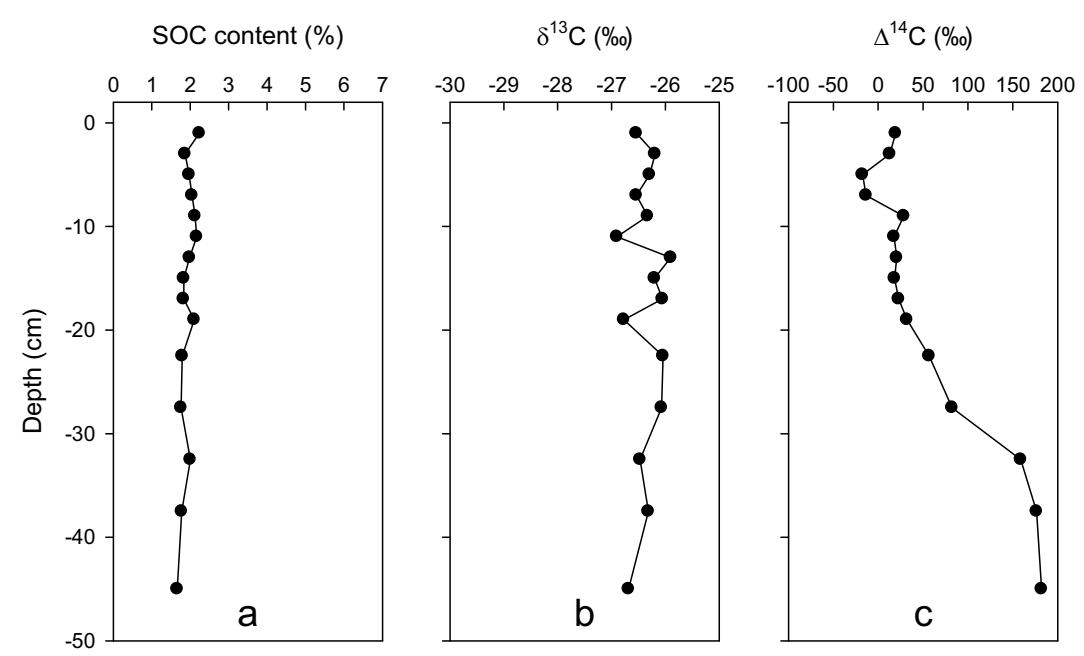

Figure 3 Vertical patterns in the sediment core from the Bruguiera gymnorrhiza + Kandelia candel site (site 2): (a) SOC content; (b) SOC $\delta^{13} \mathrm{C}$; (c) SOC $\Delta^{14} \mathrm{C}$.

\section{DISCUSSION}

\section{Comparison of SOC Storage of High and Middle Tidal Mangrove Stands}

There was a large difference in SOC storage between site 1 (high) and site 2 (middle) tidal mangrove stands. SOC density at site 2 (located at the middle tidal flat, $243.65 \mathrm{Mg} \mathrm{ha}^{-1}$ ) was only $55.28 \%$ of that at site 1 (located at the high tidal flat, $431.77 \mathrm{Mg} \mathrm{ha}^{-1}$ ). This difference was largely due to differences in SOC contents in the top $20 \mathrm{~cm}$ of sediment layers (see Figures 2a, 3a), with mean SOC contents of $5.31 \%$ and $2.02 \%$ at site 1 and site 2 , respectively. The variability of the surface SOC contents probably resulted from tidal flushing effects.

SOC density in mangrove forests varies greatly at different sites. SOC densities at $0-100 \mathrm{~cm}$ depth were estimated to be $57.3 \mathrm{Mg} \mathrm{ha}^{-1}$ in Japan, $288.65 \mathrm{Mg} \mathrm{ha}^{-1}$ in Hong Kong, and $592 \mathrm{Mg} \mathrm{ha}^{-1}$ in Australia (Matsui 1998; Khan et al. 2007; Zhang et al. 2007). Factors such as mangrove species composition, tree density, root biomass, and sedimentary environments all may affect SOC density.

\section{Vertical Patterns of SOC $\delta^{13} \mathrm{C}$ of High and Middle Tidal Mangrove Stands}

The variations of $\mathrm{SOC} \delta^{13} \mathrm{C}$ values as a function of depth differed greatly between the 2 sites in that SOC $\delta^{13} \mathrm{C}$ values was relatively stable with depth at the middle tidal site but gradually presented enrichment with depth at the high tidal site (see Figure 2b, 3b). At the middle tidal site, frequent tidal actions played the role of averaging out the mangrove-derived organic matter over a wide area and mixing them with the ocean-derived organic matter.

SOC $\delta^{13} \mathrm{C}$ at the surface $20 \mathrm{~cm}$ of the high tidal stand was relatively constant, reflecting the high productivity and rapid deposition of organic matter of mangrove forests (Woodroffe 1992; Jennerjahn and Ittekkot 2002; Gonneea et al. 2004). At the high tidal site, SOC $\delta^{13} \mathrm{C}$ was enriched at $20-50 \mathrm{~cm}$. This result agreed with those obtained in terrestrial forest ecosystems. In fact, the A. corniculatumdominated high tidal stand (site 1) in this study lay beyond the regular reach of the tides, where they represented an environment not greatly different from that of a terrestrial forest (Hogarth 2007). Numerous studies have indicated that, with the exception of soils in peatlands, SOC $\delta^{13} \mathrm{C}$ tended to 
become enriched with soil depth (Balesdent et al. 1993; Boutton 1996; Ehleringer et al. 2000; Wynn et al. 2006). Several factors might explain this enrichment.

First, the relatively recent burning of large quantities of fossil fuels could have resulted in reduced $\delta^{13} \mathrm{C}$ values near the surface, such that the $\delta^{13} \mathrm{C}$ values deeper in the soil seem enriched in comparison. The burning of fossil fuels since the start of the Industrial Revolution has released large quantities of $\mathrm{CO}_{2}$ with low $\delta^{13} \mathrm{C}$ values (approximately -27\%) into the atmosphere, and the $\delta^{13} \mathrm{C}$ of atmospheric $\mathrm{CO}_{2}$ has been depleted by up to $1.3 \%$ during the past $200 \mathrm{yr}$. This $\mathrm{CO}_{2}$ with low $\delta^{13} \mathrm{C}$ values has been fixed by plants and added to the SOC as the plants died. Because this plant-derived SOC has been added relatively recently to the soil, it will be most abundant near the surface. It follows that the $\delta^{13} \mathrm{C}$ value of the younger SOC near the surface will be more negative that of the older SOC in the deeper soil layers. Thus, the "enrichment" of SOC $\delta^{13} \mathrm{C}$ with depth will be expected. However, SOC $\Delta^{14} \mathrm{C}$ values at $20-50 \mathrm{~cm}$ were more than zero (see Figure 2c), indicating that SOC in these layers was formed only very recently, i.e. after the testing of atmospheric thermonuclear weapons and much later than the onset of the Industrial Revolution.

Second, roots generally have $\delta^{13} \mathrm{C}$ values 1-3\%o higher than leaves (Vonfischer and Tieszen 1995). However, the surface litter decays rapidly and little is preserved into the deep layers, and most subsurface SOC is derived from roots in mangrove forests (Middleton and McKee 2001; Gleason and Ewel 2002; Jennerjahn and Ittekkot 2002). Therefore, it seems unlikely that the enrichment at the subsurface layers in this study was due to the $\delta^{13} \mathrm{C}$ difference between roots and leaves.

Third, many studies have indicated that fractionation by microorganisms results in SOC $\delta^{13} \mathrm{C}$ enrichment with depth (Agren et al. 1996; Schweizer et al. 1999; Santruckova et al. 2000; Powers and Schlesinger 2002). Microorganisms preferentially metabolize molecules containing the lighter ${ }^{12} \mathrm{C}$, so that the remaining SOC tends to be ${ }^{13} \mathrm{C}$ enriched. Probably the enrichment in this study was attributable to this microbial fractionation.

\section{SOC Turnover of High Tidal Mangrove Stand (Site 1)}

In general, a bomb- ${ }^{14} \mathrm{C}$-based SOC turnover model was restricted to application in terrestrial ecosystems. Since the A. corniculatum-dominated high tidal stand in this study was only flooded occasionally, and the vertical distribution patterns of SOC content and $\delta^{13} \mathrm{C}$ at the site did not differ greatly from those in terrestrial forests, we took sedimentary and pedogenic environment of the high tidal stand was aerobic and similar to terrestrial environment, so the model was tried for estimating SOC turnover rates at the high tidal mangrove site.

SOC $\Delta{ }^{14} \mathrm{C}$ values at all the sediment layers of the high tidal stand, with the exception of $10-20 \mathrm{~cm}$, were greater than zero, indicating that SOC in these sections consisted of modern carbon polluted by atmospheric thermonuclear weapons testing. The bomb- ${ }^{14} \mathrm{C}$-based SOC turnover model indicated that SOC turnover times at the subsurface layers ranged from several years to decades (see Table 3 ).

There was bomb ${ }^{14} \mathrm{C}$ found as deep as $50 \mathrm{~cm}$ in this study. Previous studies have found that modern $\mathrm{C}$ is usually restricted to the top 25-cm soil layers (Bol et al. 1999; Wang et al. 2005). It is possible that modern $\mathrm{C}$ detected in this study was mainly derived from mangrove roots. Root biomass can account for half of the total biomass in mangrove forests (Briggs 1977), and fine-root biomass might account for $66 \%$ of the total root biomass (Komiyama et al. 1987). Mangrove roots, including pneumatophore and buttress-like roots, penetrated deep into the sediment and were the main input of the deep SOC (Fujimoto et al. 1999; Gleason and Ewel 2002). This hypothesis agrees with the root distribution in this study (see Table 2). 


\section{$J$ P Zhang et al.}

SOC turnover times at $20-50 \mathrm{~cm}$ of the A. corniculatum-dominated high tidal stand were 4.44$26.04 \mathrm{yr}$. In general, SOC turnover is much slower deeper in the sediment than near the surface. However, Fontaine et al. (2007) found that a fresh supply of organic C could provide an energy source for microorganisms at the subsurface layers. A fresh supply of organic $\mathrm{C}$ could, therefore, increase the rate of SOC turnover at the subsurface layers. In this study, we suspect that dead mangrove roots provided a fresh supply of organic $\mathrm{C}$ and shortened the SOC turnover time in these deeper sediment layers. SOC turnover times were years to decades in the subsurface sediment layers in the high tidal mangrove stand, which was largely different from conventional viewpoints that SOC turnover in mangrove forests is very slow irrespective of tidal location or local variability.

As for SOC of the middle tidal stand (site 2), the bomb- ${ }^{14} \mathrm{C}$ turnover model could not be applied to the waterlogged sediment because the middle tidal flat was regularly flooded, and turnover there was primarily constrained by a lack of oxygen. We also suspect that the fresh supply of organic C by the dead mangrove roots result in increased $\Delta{ }^{14} \mathrm{C}$ values in the $20-50 \mathrm{~cm}$ layer of the middle tidal stand (Figure 2c).

\section{CONCLUSIONS}

The results of this paper, which are based on measurement of ${ }^{14} \mathrm{C}$ and ${ }^{13} \mathrm{C}$ isotopes in sediment cores, indicate that SOC storage and turnover were greatly constrained by tidal processes. SOC density was $431.77 \mathrm{Mg} \mathrm{ha}^{-1}$ for the high tidal stand and $243.65 \mathrm{Mg} \mathrm{ha}^{-1}$ for the middle tidal stand since the latter, but not the former forest experienced frequent tidal flushing of the surface sediment. SOC was $\delta^{13} \mathrm{C}$ enriched with depth at the subsurface sediment layers of the high tidal stand, possibly due to preferential microbial decomposition.

A bomb- ${ }^{14} \mathrm{C}$-based turnover model was used to estimate SOC turnover times of the high tidal stand since the sedimentation environment there was similar to terrestrial soils and was suitable for the model. Turnover times were 4.44-26.04 yr for the subsurface SOC of the high tidal stand. Mangrove roots probably accounted for the shorter turnover times at the subsurface sediment layers. Tidal locations should be considered in the future study of SOC turnover. Also, further quantification of root dynamics and samplings of sediment cores are also required to increase our understanding of $\mathrm{C}$ turnover in the belowground mangrove ecosystem.

\section{ACKNOWLEDGMENTS}

We thank Professor Li Zhi'an, Senior Engineer Zhang Qianmei, and Mr Zou Bi (the South China Botanical Garden); and Mr Xu Fanghong of the Administration of Zhanjiang Mangrove National Natural Reserve for their help in field sampling. We also thank the reviewers for their valuable comments on the early version of the manuscript. This research was sponsored by funds of The Ministry of Science and Technology (No. 2007BAC28B04), Chinese Academy of Sciences (No. KSCX2SW-132), and the National Natural Science Foundation of China (No. 40473002).

\section{REFERENCES}

Agren GI, Bosatta E, Balesdent J. 1996. Isotope discrimination during decomposition of organic matter: a theoretical analysis. Soil Science Society of America Journal 60:1121-6.

Arnold K. 1986. Methods of Soil Analysis. Part 1. Physical and Mineralogical Methods. Madison: Soil Science Society of America.
Balesdent J, Girardin C, Mariotti A. 1993. Site-related $\delta^{13} \mathrm{C}$ of tree leaves and soil organic-matter in a temperate forest. Ecology 74:1713-21.

Bol RA, Harkness DD, Huang Y, Howard DM. 1999. The influence of soil processes on carbon isotope distribution and turnover in the British uplands. European Journal of Soil Science 50:41-51. 


\section{Sedimentary OC Storage, Turnover of Tidal Mangrove Stands}

Bouillon S, Bottcher ME. 2006. Stable isotopes in biogeosciences - preface. Organic Geochemistry 37: $1197-9$.

Bouillon S, Dahdouh-Guebas F, Rao A, Koedam N, Dehairs F. 2003. Sources of organic carbon in mangrove sediments: variability and possible ecological implications. Hydrobiologia 495:33-9.

Bouillon S, Connolly RM, Lee SY. 2008. Organic matter exchange and cycling in mangrove ecosystems: recent insights from stable isotope studies. Journal of Sea Research 59:44-58.

Boutton TW. 1996. Stable carbon isotope ratios of soil organic matter and their use as indicators of vegetation and climate change. In: Boutton TW, Yamasaki S, editors. Mass Spectrometry of Soils. New York: Marcel Dekker. p 311-39.

Briggs SV. 1977. Estimates of biomass in a temperate mangrove community. Australian Journal of Ecology 2:369-73.

Chen QQ, Sun YM, Shen CD, Peng SL, Yi WX, Li Z, Jiang MT. 2002. Organic matter turnover rates and $\mathrm{CO}_{2}$ flux from organic matter decomposition of mountain soil profiles in the subtropical area, south China. Catena 49(3):217-29.

Cherkinsky AE, Brovkin VA. 1993. Dynamics of radiocarbon in soils. Radiocarbon 35(3):363-7.

Chmura GL, Anisfeld SC, Cahoon DR, Lynch JC. 2003. Global carbon sequestration in tidal, saline wetland soils. Global Biogeochemical Cycles 17:1111, doi: 10.1029/2002GB001917.

Choi YH, Wang Y. 2004. Dynamics of carbon sequestration in a coastal wetland using radiocarbon measurements. Global Biogeochemical Cycles 18: GB4016, doi:10.1029/2004GB002261.

Ehleringer JR, Buchmann N, Flanagan LB. 2000. Carbon isotope ratios in belowground carbon cycle processes. Ecological Applications 10:412-22.

Fontaine S, Barot S, Barre P, Bdioui N, Mary B, Rumpel C. 2007. Stability of organic carbon in deep soil layers controlled by fresh carbon supply. Nature 450(7167): $277-80$.

Fujimoto K, Imaya A, Tabuchi R, Kuramoto S, Utsugi H, Murofushi T. 1999. Belowground carbon storage of Micronesian mangrove forests. Ecological Research 14:409-13.

Gleason SM, Ewel KC. 2002. Organic matter dynamics on the forest floor of a Micronesian mangrove forest: an investigation of species composition shifts. Biotropica 34:190-8.

Gonneea ME, Paytan A, Herrera-Silveira JA. 2004. Tracing organic matter sources and carbon burial in mangrove sediments over the past 160 years. Estuarine, Coastal and Shelf Science 61:211-27.

Harkness DD, Harrison AF, Bacon PJ. 1986. The temporal distribution of 'bomb' ${ }^{14} \mathrm{C}$ in a forest soil. Radiocarbon 28():328-37.

He BY, Lai TH, Fan HQ, Wang WQ, Zheng HL. 2007.
Comparison of flooding-tolerance in four mangrove species in a diurnal tidal zone in the Beibu Gulf. Estuarine, Coastal and Shelf Science 74:254-62.

Hogarth P. 2007. The Biology of Mangroves and Seagrasses. Oxford: Oxford University Press. 273 p.

Hua Q, Barbetti M. 2004. Review of tropospheric bomb ${ }^{14} \mathrm{C}$ data for carbon cycle modeling and age calibration purposes. Radiocarbon 46(3):1273-98.

Jennerjahn TC, Ittekkot V. 2002. Relevance of mangroves for the production and deposition of organic matter along tropical continental margins. Naturwissenschaften 89:23-30.

Khan MNI, Suwa R, Hagihara A. 2007. Carbon and nitrogen pools in a mangrove stand of Kandelia obovata (S., L.) Yong: vertical distribution in the soil-vegetation system. Wetlands Ecology and Management 15: 141-53.

Komiyama A, Ogino K, Aksornkoae S, Sabhasri S. 1987. Root biomass of a mangrove forest in Southern Thailand. 1. Estimation by the trench method and the zonal structure of root biomass. Journal of Tropical Ecology 3:97-108.

Kristensen E, Bouillon S, Dittmar T, Marchand C. 2008. Organic carbon dynamics in mangrove ecosystems: a review. Aquatic Botany 89:201-19.

Levin I, Kromer B. 2004. The tropospheric ${ }^{14} \mathrm{CO}_{2}$ level in mid-latitudes of the Northern Hemisphere (19592003). Radiocarbon 46(3):1261-72.

Levin I, Hammer S, Kromer B, Meinhardt F. 2008. Radiocarbon observations in atmospheric $\mathrm{CO}_{2}$ : determining fossil fuel $\mathrm{CO}_{2}$ over Europe using Jungfraujoch observations as background. The Science of the Total Environment 391:211-6.

Matsui N. 1998. Estimated stocks of organic carbon in mangrove roots and sediments in Hinchinbrook Channel, Australia. Mangroves and Salt Marshes 2:199204.

McKee KL. 1993. Soil physicochemical patterns and mangrove species distribution-reciprocal effects? The Journal of Ecology 81(3):477-87.

Middleton BA, McKee KL. 2001. Degradation of mangrove tissues and implications for peat formation in Belizean island forests. Journal of Ecology 89:81828.

Powers JS, Schlesinger WH. 2002. Geographic and vertical patterns of stable carbon isotopes in tropical rain forest soils of Costa Rica. Geoderma 109(1-2):14160.

Ren H, Jian SG, Lu HF, Zhang QM, Shen WJ, Han WD, Yin ZY, Guo QF. 2008. Restoration of mangrove plantations and colonisation by native species in Leizhou bay, South China. Ecological Research 23:401-7.

Robert L, Morlang A, Gorman L. 1997. Monitoring the coastal environment. Part 2. Sediment sampling and geotechnical methods. Journal of Coastal Research 13:308-30.

Santruckova H, Bird MI, Lloyd J. 2000. Microbial pro- 


\section{$J$ P Zhang et al.}

cesses and carbon-isotope fractionation in tropical and temperate grassland soils. Functional Ecology 14: $108-14$.

Schweizer M, Fear J, Cadisch G. 1999. Isotopic $\left({ }^{13} \mathrm{C}\right)$ fractionation during plant residue decomposition and its implications for soil organic matter studies. Rapid Communications in Mass Spectrometry 13:1284-90.

Staddon PL. 2004. Carbon isotopes in functional soil ecology. Trends in Ecology \& Evolution 19:148-54.

Stuiver M, Polach H. 1977. Discussion reporting of ${ }^{14} \mathrm{C}$ data. Radiocarbon 19(3):355-63.

Tam NFY, Wong YS. 1998. Variations of soil nutrient and organic matter content in a subtropical mangrove ecosystem. Water, Air, \& Soil Pollution 103:245-61.

Tamooh F, Huxham M, Karachi M, Mencuccini M, Kairo JG, Kirui B. 2008. Below-ground root yield and distribution in natural and replanted mangrove forests at Gazi bay, Kenya. Forest Ecology and Management 256:1290-7.

Telles EDC, de Camargo PB, Martinelli LA, Trumbore SE, de Costa ES, Santos J, Higuchi N, Oliveira RC. 2003. Influence of soil texture on carbon dynamics and storage potential in tropical forest soils of Amazonia. Global Biogeochemical Cycles 17(2):1040, doi: 10.1029/2002GB001953.

Townsend AR, Vitousek PM, Trumbore SE. 1995. Soil organic-matter dynamics along gradients in temperature and land-use on the island of Hawaii. Ecology 76: $721-33$.

Trumbore SE. 1996. Applications of accelerator mass spectrometry to soil science. In: Boutton TW, Yamasaki S, editors. Mass Spectrometry of Soils. New York: Marcel Dekker. p 311-39.
Vogel JS, Nelson DE, Southon JR. 1987. ${ }^{14} \mathrm{C}$ background levels in an accelerator mass-spectrometry system. Radiocarbon 29(3):323-33.

Vonfischer JC, Tieszen LL. 1995. Carbon-isotope characterization of vegetation and soil organic-matter in subtropical forests in Luquillo, Puerto Rico. Biotropica 27:138-48.

Wang L, Ouyang H, Zhou CP, Zhang F, Song MH, Tian YQ. 2005. Soil organic matter dynamics along a vertical vegetation gradient in the Gongga Mountain on the Tibetan Plateau. Journal of Integrative Plant and Biology 47:411-20.

West JB, Bowen GJ, Cerling TE, Ehleringer JR. 2006. Stable isotopes as one of nature's ecological recorders. Trends in Ecology \& Evolution 21:408-14.

Woodroffe C. 1992. Mangrove sediments and geomorphology. In: Robertson A, Alongi D, editors. Tropical Mangrove Ecosystems. Washington, DC: American Geophysical Union. p 7-41.

Wynn JG, Harden JW, Fries TL. 2006. Stable carbon isotope depth profiles and soil organic carbon dynamics in the lower Mississippi Basin. Geoderma 131:89109.

Zhang HB, Luo YM, Wong MH, Zhao QG, Zhang GL. 2007. Soil organic carbon storage and changes with reduction in agricultural activities in Hong Kong. Geoderma 139:412-9.

Zhang JP, Shen CD, Ren H, Wang J, Han WD. 2012. Estimating change in sedimentary organic carbon content during mangrove restoration in southern China using carbon isotopic measurements. Pedosphere 22(1):58-66. 